\title{
The taxonomic composition of the microbial community of the southern chernozem when introducing plant substrates
} and their destructors

Kameneva I. ${ }^{1}$, Melnichuk T. ${ }^{1}$, Abdurashitov S. ${ }^{l}$, Andronov E. ${ }^{2}$, Yakubovskaya A. ${ }^{l}$ Gritchin M..${ }^{l}$, Prikhodko A. ${ }^{l}$

${ }^{1}$ FSBSI "Research Institute of Agriculture of Crimea", Simferopol; ${ }^{2}$ FSBIS “All-Russian Research Institute of Agricultural Microbiology", St. Petersburg, Russia

E-mail: irina.kameneva.7@mail.ru

Key message. The influence of green manure (phacelia), wheat straw, and cellulolytic association on the taxonomic structure of chernozems southern in the steppe zone of the Crimea was studied. Changes in the proportion among representatives of 11 phila, 14 bacteria, and 2 archaea were established.

Keywords: chernozems southern microbiome, phacelia green manure, wheat straw, cellulosolytic association of microorganisms Microbial communities of the soil are the most important factors in the transformation of organic compounds, nutrients cycle, increasing soil fertility and self-purification. To improve the efficiency of these processes, research aimed at managing the functional and taxonomic structure of the microbiome by introducing plant mass and active microorganisms for their destruction is relevant and promising.

The purpose of the research was to determine the taxonomic composition of the microbiome of the chernozems southern after the addition of green manure and straw, as well as their destructors.

In the stationary three-field short crop rotation located in the Department of the field crops of the FSBSI "Research Institute of Agriculture of Crimea" (central part of the steppe Crimea), we studied the taxonomic composition of the microbiome of chernozems southern low humus on loesslike light clays during the incorporation of phytomass of phacelia (Phacelia tanacetifolia Bent.) and winter wheat (Triticum aestivum L.). We processed this phytomass with the cellulosolytic association (CA) of microorganisms in the laboratory. The taxonomic composition of the soil microbiome was determined using high-throughput sequencing of 16S rRNA gene libraries.

Assessment of the microbiome of the chernozems southern showed changes among 11 phyla of fungi, of which five exceeded $1 \% ; 14$ phyla of bacteria, of which 6 were dominant; the same for Thaumarchaeota - representative of archaea.

The dominant observed eukaryotes were Ascomycota phylum. Their proportion was in the range of $30.0-45.1 \%$ depending on the introduced plant substrates and CA. The increase in the share of Ascomycota was more significant after straw incorporation, namely $4.4 \%$ more than in the control variant. In case of phacelia incorporation, the excess was $1.8 \%$ only. Among minor eukaryotes, Cercozoa has been identified, the most common representatives of which are commonly found in nutrient-rich soils.

Among the major representatives of bacteria, three phyla were identified: Actinobacteria, Bacteroidetes, and Proteobacteria, which respond by increasing the proportion when phacelia and straw were incorporated (both without treatment and inoculated with CA).

Thus, the influence of green manure (phacelia), wheat straw, and cellulolytic association of microorganisms on the taxonomic structure of chernozems southern in the steppe zone of the Crimea was established. The work was carried out within the framework of the state task of fundamental research No. 0834-2019-0005 and supported by RFBR grant r_a No.19-416-910003.

\section{Таксономический состав микробного сообщества чернозема южного при внесении растительных субстратов} и их деструкторов

Каменева И.А. ${ }^{l}$, Мельничук T.Н. ${ }^{1}$, Абдурашитов С.Ф. ${ }^{1}$, Андронов E.E. ${ }^{2}$, Якубовская А.И. ${ }^{l}$, Гритчин М.В. ${ }^{l}$, Приходько А.В. ${ }^{l}$

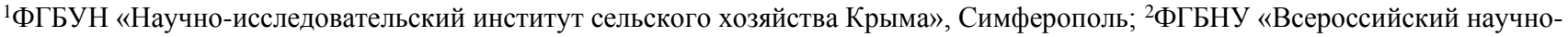
исследовательский институт сельскохозяйственной микробиологии»; Санкт-Петербург, Россия

Аннотация. Изучено влияние сидерата (фацелия), соломы пшеницы и целлюлозолитической ассоциации на таксономическую структуру чернозема южного степной зоны Крыма. Установлены изменения доли среди представителей 11 фил грибов, 14 бактерий и 2 архей.

Ключевые слова: микробиом чернозема южного, сидерат фацелия, солома пшениць, целлюлозолитическая ассоциация микроорганизмов

Микробные сообщества почвы являются важнейшим фактором трансформации органических соединений, круговорота биогенных элементов, повышения плодородия и самоочищения почвы. Для повышения эффективности этих процессов актуальны и перспективны исследования, направленные на управление функциональной и таксономической структурой микробиома посредством внесения растительной массы и активных микроорганизмов для их деструкции.

Цель исследований - установить таксономический состав микробиома чернозема южного при внесении сидерата и соломы и их деструкторов.

В стационарном трехпольном коротко-ротационном полевом севообороте отделения полевых культур ФГБУН «НИИСХ Крыма», расположенного в центральной части степного Крыма, исследовали таксономический состав микробиома чернозема южного малогумусного на лессовидных легких глинах при заделке фитомассы фацелии (Phacelia tanacetifolia Bent.) в фазу цветения и соломы озимой пшеницы (Tríticum aestivum L.), обработанных собранной в лабораторных условиях целлюлозолитической ассоциацией микроорганизмов (ЦА). Таксономический состав микробиома почвы устанавливали с использованием высокопроизводительного секвенирования библиотек гена $16 \mathrm{~S}$ рPHК.

Оценка микробиома чернозема южного показала изменения среди 11 фил грибов, из которых доля пяти превышала 1 \%, и 14 фил бактерий, из них 6 доминирующих, как и Thaumarchaeota - представительницы архей.

Наиболее высокое представительство эукариот отмечено у филы Ascomycota, где доля находилась в пределах 30,0-45,1 \%, в зависимости от внесенных растительных субстратов и ЦА. Увеличение доли Ascomycota было более существенным при внесении соломы - на 4,4 \% выше контроля, чем при заделке фацелии, где превышение составило 1,8 \%. Среди минорных эукариотов выявлена Cercozoa, наиболее распространенные представители которой обычно встречаются в богатых питательными веществами почвах.

Среди мажорных представителей бактерий обозначены три филы: Actinobacteria, Bacteroidetes и Proteobacteria, реагирующие увеличением доли при внесении фацелии и соломы, как без обработки, так и инокулированных ЦА.

Таким образом, установлено влияние сидерата (фацелия), соломы пшеницы и целлюлозолитической ассоциации микроорганизмов на таксономическую структуру чернозема южного степной зоны Крыма.

Работа выполнена в рамках государственного задания фундаментальных исследований № 0834-2019-0005 и при поддержке гранта РФФИ р_а №19-416-910003. 